\title{
Signet Ring Cell Breast Carcinoma
}

National Cancer Institute

\section{Source}

National Cancer Institute. Signet Ring Cell Breast Carcinoma. NCI Thesaurus. Code C5175.

An invasive breast adenocarcinoma characterized by the presence of malignant epithelial cells with signet ring appearance. 